\title{
THE GUESDISTS AND THE SMALL FARMER: EARLY EROSION OF FRENGH MARXISM ')
}

The internal conflicts of the socialist movement before 1914 grew out of the antagonism between orthodox Marxists and reformist Socialists, or were at least closely related to that antagonism, as for instance the conflict between the labor unions and the party leadership in Germany in 1905-6. This running battle of pre-war days, which set the scene for the splitting of the movement during the first World War, reached its most spectacular expression in Germany in Bebel's attack on the Revisionists at the Dresden party convention of 1903 . But the conflict unfolded first in France, and it was in France rather than in Germany that the fundamental issues were posited most clearly. In 1882 , nine years before Georg von Vollmar in his "Eldorado" addresses in Munich started the revolt of the German Revisionists and fourteen years before Eduard Bernstein in his "Evolutionary Socialism" published the first comprehensive exposition of Revisionist ideas, Paul Brousse broke with the Marxist leaders, Jules Guesde and Paul Lafargue, whom he forced out of the Fédération des travailleurs socialistes de France, thus transforming the latter into a Possibilist party, whereas the expelled Marxists formed the Parti ouvrier. Even the debates at Dresden - and subsequently at the International Socialist Congress at Amsterdam - developed from a French issue - namely, the acceptance of a position in a liberal cabinet by the French reformist, Alexandre Millerand.

Although the struggles within the German and French socialist movements were so closely interrelated as to form two aspects of the same conflict, the rhythm was different in the two countries. Whereas in Germany, once the debate had started, it developed with increasing

\footnotetext{
1 In collecting the material for this article, I have been most effectively assisted by the staff of the International Institute of Social History. I should like to express my special gratitude to Mr. B. van Tijn who deciphered the Bonnier letters and had them transcribed for my use. I also wish to thank Professor Georg Eckert of the Pedagogical Academy of Braunschweig for having called my attention to sources of information on Charles Bonnier's life.
} 
bitterness up to the clash at Dresden, and only abated afterwards when the Marxist orthodoxy was pushed into a center position by the emergence of an extreme Left wing under the influence of Rosa Luxemburg, Anton Pannekoek and Lenin, in France there was a temporary rapprochement of the two wings between the early I $890^{\circ} \mathrm{s}$ and the end of the decade. In this period the socialists of all factions Marxists, Possibilists, Blanquists, Allemanists (a splinter from the Possibilists leaning toward a sort of anarchism) and the new group of Independents under Jean Jaurès and Alexandre Millerand, collaborated closely in the Chamber, and the idea of organizational unification of French socialism was gaining ground. This development would have been impossible if the Marxist leaders had not shown a conciliatory spirit toward the other groups in strong contrast to their earlier and especially to their later attitude. In I 896, they even accepted in principle a unification program of an essentially reformist character, drafted by Millerand - the program of Saint-Mandé. In all probability, the unification of French socialism would have occurred before 1900 if it had not been for the difference of opinions on the Dreyfus affair and especially for the Millerand crisis, which not only revived the conflict, but aggravated its bitterness to an intensity not reached before.

The conciliatory attitude of the Marxists toward the moderates between 1893 and 1899 has been noticed by several writers on French socialist history. Georges Weill reports that Gabriel Deville, who at the time "... was still one of the faithful of Marxism, conceded in I 895 that previously he had overestimated the possible results of a victory through an act of force; he added that those who 'believe in the unchanging efficacy of the old revolutionary attitudes take an antiquated position'. Jules Guesde, of all party speakers the one most in the habit of using acrid words, concealed a similar moderation behind violent formulas." 1

Aaron Noland writes: "The retreat of the Guesdists from their early revolutionary ideology, a retreat rendered manifest by the conduct of the Guesdist Deputies, was a development of major importance in the history of the French Socialist movement. Why did the Guesdists, ostensibly exponents of orthodox Marxism in the eighties, definitely cease to be revolutionary Socialists in the nineties?" In Noland's opinion, the decisive factor was the effort of the Guesdist deputies in the Chamber to obtain the enactment of social reform legislation. Although this effort was originally undertaken with an

${ }^{1}$ Georges Weill, Histoire du mouvement social en France (1852-1924), Paris (Alcan) 1924, p. 308. 
eye to electoral success, it committed the party to work within the capitalist order and the institutional structure of political democracy and thus "modified the doctrine and objectives of the party." 1

Whatever may be the truth in this explanation by Noland, the conversion of the French Marxists to reformism was so fast and - although it did not prove very durable - was seemingly so complete as to make it hard to understand that the change of mind should have been produced merely by the experience of working for social improvement in general by legislative strategy. Indeed, there was a more specific motive for the Guesdists to modify their antagonism toward the evolutionary concept of socialism: Within the International, they found themselves separated from the Marxists of other countriesand especially from the German Marxists - by differences of opinion on the agrarian question, and on the other hand a similarity existed between the approach of the German Revisionists, especially Georg von Vollmar, and that of the Guesdists to the problems of agriculture.

In the $1890^{\circ}$ 's, France was still a prevailingly agricultural country, and the pace of its industrialization was less rapid than that of Germany. The German socialists could hope that the scarcity of their footholds in rural areas would not prove too much of a handicap in the end, since urbanization was progressing rapidly; but for the French socialists the acquisition of voting strength among the small farmers seemed vital. The Guesdists were very much alive to this fact, and in I 892 their congress at Marseilles adopted an agricultural program, mainly in the interest of agricultural laborers, sharecroppers and other tenant farmers. The party leadership gained the impression that this program had been favorably received by the farming population, and therefore had the party congress of Nantes in I 894 enact an even more far-reaching program of support for the small agriculturists. The details are unimportant today; the essential point was the tendency to preserve small-scale agriculture, in defiance of the Marxist theorem that the small farmer was just as much doomed as the small urban master craftsman. ${ }^{2}$

This deviation from the creed aroused the indignation of leading

${ }^{1}$ Aaron Noland, The Founding of the French Socialist Party, Cambridge (Harvard University Press) 1956, p. 53.

2 The Marxist theorem was not formally abandoned, since the preamble to the program recognized that "the condition of agriculture characterized by parcellization of holdings is unavoidably doomed" and merely maintained that, "it is not up to the socialists to accelerate this development, since their task is not to seperate property from labor but to unite these two factors of production in the same persons." Douzième Congrès National du Parti Ouvrier Français, tenuà Nantes du 14 au I 6 Septembre 1894 , Lille (Imp. Ouvrière G. Delory) 1894, p. I9. The practical purpose of the proposed measures however, could only be to save small agricultural property from extinction. 
Marxists within the International - all the more because similar tendencies appeared in the German party and in other national sections. Georg von Vollmar, the leader of the Bavarian wing of German Social Democracy, demanded a "positive kind of action through postulates which will protect farmers and agricultural laborers against capitalist exploitation here and now and at the same time open the way (anbabnen) to the advanced form of economic life of the future." 1 The advocates of a positive agricultural program both in Germany and France stressed the importance of an improvement of farmers' conditions and thereby put the limelight on a question which the orthodox Marxists wished to avoid: how the party could advocate reforms under capitalism - and without such advocacy its electoral success would have been impossible - and still profess its belief in revolutionary dialectics. The French Parti ouvrier, in the preamble to its program of Nantes, had stated that it, "unlike the anarchists, in striving for a change in the social system, does not count on an intensification or extension of misery, but expects the liberation of labor and of all society from the organization and the common effort of the workers in the country as well as in the cities..."2 But the theory of increasing misery is a necessary element of the dialectic mechanism of history and therefore an indispensable part of Marxist philosophy; if it was difficult or impossible to reconcile demands for meliorative industrial legislation with dialectic philosophy, the adding of an agrarian program promising protection to farmers was bound to make the contradiction even clearer. Whereas protective legislation for workers would at least benefit the rising class, measures to save the small farmer would counteract technological progress, which alone - according to Marx - guaranteed the victory of socialism. The Marxist doctrinaires had good reasons for their anger against the advocates of a "positive" agricultural policy.

Friedrich Engels himself, shortly before his death, denounced the programs of Marseilles and Nantes as inconsistent, futile and opportunistic. He condemned the Guesdist effort "to win the small farmer today or tomorrow, if possible already for the next election." 3 He wrote: "Bluntly speaking, in view of the small farmer's economic position, the kind of education he has received and the prejudices which his isolated way of life have caused and which are continually nourished by the bourgeois press and the propaganda of the large

1 Protokoll über die Verhandlungen des Parteitages der Sozialdemokratischen Partei Deutschlands zu Frankfurt, Berlin (Verlag Vorwärts) 1894, p. 152.

2 Douzième Congrès National du Parti Ouvrier Français, p. 20.

${ }^{3}$ Friedrich Engels, Die Bauernfrage, p. 301. 
estate owners, we can win him now or in the near future only by giving him promises which we know we cannot keep... But it is not to our interest to win the farmer today or tomorrow and to have him defect from our ranks tomorrow or the day after tomorrow when we fail to keep our promises. The farmer who expects us to perpetuate his dwarf property is not acceptable to us as a party member..." 1

The other German Marxists, not enjoying the same international authority as Engels, for the most part refrained from direct denunciation of the French program, 'but their criticism of similar tendencies within the German party implied a condemnation of the program of Nantes; moreover, Karl Kautsky, who after the death of Engels became the outstanding guardian of the Marxist creed against rightist and leftist deviations, continued to fire shots at the French party, taking his ammunition from the Engels article. ${ }^{2}$

The French socialists, on the other hand, and especially the Guesdists, proud of the appeal of their agricultural postulates, resented the criticism, expressed and implied, and developed some sympathy for the Revisionists who were attacked by the same Marxist group and whose attitude toward the farmer was in harmony with the principles of the Nantes program.

A fortunate accident offers an opportunity to study the effect of the

1 Ibid. What caused Engels publicly to criticize the socialist attempts to win farmer support was the simultaneous appearance of these attempts in the French and German movements; he apparently feared that these parallel tendencies might so reinforce each other as to drive the parties deep into opportunism. He viewed with some tolerance the content of the Nantes program, as distinguished from the circumstances leading to its adoption. On December 18, 1894, he wrote to Paul Lafargue: "The program itself contains only one article which is really objectionable [qui ne vaille rien]: the legal limitation of the interest rate, i.e. the restitution of the old usury laws..." Friedrich Engels, Paul et Laura Lafargue, Correspondance, Emile Bottigelli, ed., Paris (Editions Sociales), 1959. Vol. III, p. 38r. Previously, on November 22, he had written: "If I am not in accord with what the resolution of Nantes actually says, I am at least in accord with what it wanted to say", and he assured Lafargue that in his forthcoming article in Die Neue Zeit he would try to be as conciliatory as possible; but he added: "... after the misuse of the resolution in Germany it is not possible to pass it over in silence. - Really, you have permitted yourselves to be drawn a little too much to the opportunist side. At Nantes you were at the point of sacrificing the future of the party to the success of the moment. There is still time for you to arrest the trend, and if my article contributes to this effect, I shall congratulate myself. In Germany, where Vollmar permits himself to extend to the large farmers of Bavaria with holdings of from to to 30 hectares the promises which you made to the small French farmers, Bebel has taken up the gauntlet..." (l.c., p. 373).

2 For instance, in criticizing the draft program which the agricultural committee of the German party had presented, Kautsky wrote that the task of the committee had been insoluble from the outset and added: "Some time ago, our French comrades have mobilized all their acumen for the purpose of drafting an agrarian program, only to produce a proposal even more objectionable than that of our committce." Karl Kautsky, Unser neuestes Programm, in: Die Neue Zeit, XIII: 2, 1894-95, p. 617. 
agriculture controversy on the general attitude of the Guesdists toward the struggle within world socialism. A loyal friend of Jules Guesde, Charles Bonnier, held a position at the University of Oxford in French literature, and the letters which he wrote to Guesde in the middle of the I 890 's are preserved in the Guesde Archives of the International Institute of Social History. Bonnier had taken his Ph.D at the University of Halle and wrote German fluently enough to be a frequent contributor to Die Neue Zeit. As long as Engels was alive, Guesde used Bonnier as a sort of ambassador to the grand old man of international socialism. ${ }^{1}$

The most interesting of the Bonnier letters is dated December 2, I 894; thus it was written shortly before Engels' article on the agrarian program appeared in Die Neue Zeit. Its relative passages read as follows:

"The article by Engels will appear next week in the Neue Zeit; in this week's edition there is a reply by Kautsky, who says nothing that could be called precise. ${ }^{2}$ This is always the trouble with those who oppose our program or that of the Bavarians: they never offer anything positive. One is reminded of Gautier's word that the critic is a coward, because one cannot hit back at him ('parce qu'on ne peut lui rendre coup pour coup'). In other words, the fundamentalists (gens à principe) have produced no idea, no plan, nor have they told us what their method would be. We shall see what Engels has to say.

In the meantime, I believe (just my opinion, please note) that we can hold our fire;

1 Sometimes, the ambassador seems to have aggravated rather than abated dissensions, for instance in 1893 when he conveyed to Engels the sense of grievance of the Parti ouvrier against the German Social Democrats for not living up to their alleged promises of stopping all work on May ist. Engels remonstrated against the "idea of directing the European labor movement from Oxford," spoke sarcastically of Bonnier's "enormous urge to activity" and called him "Cato censorius Bonnier." (See Gustav Mayer, Friedrich Engels, Den Haag (Martinus Nijhoff) I934, vol. II, pp. 5o2f. Bonnier's relations to Engels are mentioned in several other passages of the book.) This episode, however, seems to have been only a temporary interruption of the generally friendly relations between Engels and Bonnier, and the latter also had amicable conversations with Eduard Bernstein, then living as an exile in London. (See Eduard Bernstein, The Years of My Exile. Translated by Bernard Miall, London (Parsons) I92 I, pp. 2 I 3 f.)

2 Kautsky's article (Das Erfurter Programm und die Landagitation, in: Die Neue Zeit, XIII : 1, I 894-95, pp. $278 \mathrm{ff}$.) is a defence against an attack on his Marxist orthodoxy. During the controversy about the agrarian program within the German party, some advocates of the new program had claimed that Kautsky in his commentary on the party program - Karl Kautsky, Das Erfurter Programm, Stuttgart (J. W. Dietz) I 892 - had also recommended a policy of protecting the small farmer. In his article Kautsky declares that he has been misunderstood and that he is as much as anybody opposed to a policy of promising the farmer any protection in his role as a producer cultivating his own property; in his commentary on the program Kautsky had explained that the party should make the farmer realize the hopelessness of his position and his interest in a new form of society which would give him another foundation for his existence. Those farmers who refused to accept this position of the party were to be regarded as enemies. 
I have replied to Adler only because he visualized us as going beyond Vollmar's position (parce qu'il nous visait au-dessus de Vollmar). But the only thing that we can say now is that we are waiting for 'their' program. Do you think that I am going too far? It amuses me to see that the heavier the blows which the German comrades exchange, the more they praise the unity and fraternity within their party...

At this moment the two camps are sharply divided. Bebel has been somewhat too much of a 'dictator', whereas Vollmar has been leaning somewhat too much toward the separatist side... L[iebknecht?] is trying to smooth the situation and is preaching unity. To sum up, they would do better to put their own house in order (de cultiver leur jardin).

One of the points on which Vollmar insists, and not without cleverness, is the contention by $B[e b e l]$ that the Bavarians were happy enough to demand and receive money from the Berliners (and he now undoubtedly regrets that this was given). Hence great indignation of the Bavarians... ${ }^{1}$

I believe that the best course we can take is not to intervene in this controversy - again, this is only my opinion. They would like to see us take sides (Je crois qu'il faut mieux, touiours selon moi, ne pas intervenir. C'est ce qu'on voudrait nous voir faire.) Adler has already taken the side of Bebel, thus violating the principle of non-intervention. If we felt any rancor this would be the time to preach unity to the Germans, who for a decade have pestered (embettés) us with same advice (refrain). That would be fun, but one has to resist the temptation.

In the controversy, the smartest debater is, as usual, Vollmar; the least clever one is $B[e b e l$ ?], because he speaks most frankly. Vollmar leans upon the decision of the Congress which has declared itself in his favor. ${ }^{2} \mathrm{He}$ asks why Bebel has a little while ago attacked the $J_{\text {zingen }}{ }^{3}$ who had mutinied against the Congress. Finally, he is indignant (or pretends to be) over the money affair.

$\mathrm{B}$ [ebel] finds himself in a pitiable ( fichue) and even ironical (assez drôle) situation. On the eve of the Congress he wrote, in an article directed against hostile newspapers, that the party had never been as united as at present. Now he sees this unity knocked to smithereens (son panier renversé et ses oeufs en omelette.) He wanted to make some noise to wake up the party; he will now find that he woke it up too much.

Who knows whether our position, being merely federated with the other revolutionary parties, is not fundamentally preferable to the all-too close cohesion of the German party:

${ }^{1}$ Bebel made this remark in a speech in Berlin in which he discussed the Frankfurt party congress, with bitter attacks on Vollmar, to which the South-Germans replied in the same vein. See Reinhard Jansen, Georg von Vollmar, Düsseldorf i958, p. 55 .

2 Here the reference is apparently to the Frankfurt party Congress, which left Bebel dissatisfied, as he expressed in his Berlin speech (see above, footnote ${ }^{1}$ ). The reason for his discontent and for Bonnier's belief that the congress had declared itself in Vollmar's favor was a resolution on the question of whether it was permissible for socialists to vote for state budgets, as the Bavarians, under Vollmar's leadership, had done in the Bavarian diet. The congress adopted a resolution, moved by Bebel, against such a positive vote only with a qualifying amendment that left the door open for a repetition of the Bavarian action. (See Protokoll über die Verhandlungen des Parteitages der Sozialdemokratischen Partei Deutschlands zu Frankfurt, p. 133.) In spite of Bebel's wrath about the emasculation of his resolution, the outcome was at best only a halfvictory for Vollmar.

${ }^{3}$ About the "revolt" of this leftist faction against the party leadership, see Franz Mehring,

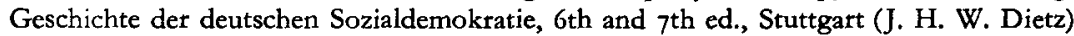
I919, IV, pp. 328 ff.; also Protokoll über die Verhandlungen des Parteitages der Sozialdemokratischen Partei Deutschlands zu Erfurt (1891), pp. 53 ff. and passim. 
The latter is like a Macedonian phalanx (excuse the classical analogy!) which cannot march across uneven ground.

We have always our own separate and autonomous party, and in the event of a "dislocation" we can fall back on that position. In Germany, I foresee a struggle which will not come to an end very soon. V[ollmar] is too strong; he has entrenched himself in Bavaria, in the south of Germany, and there holds a position like that of a chief of a clan. It seems to me that - from this point of view - a few years of exceptional law ${ }^{1}$ would do the German party a lot of good. Since 1889 , it has been drifting."

This letter shows, first of all, a complete absence of solidarity with the Marxist faction within the German party, although the most fundamental issues of party strategy were at stake. In the German party debates in which August Bebel fought for the Marxist tradition with as much determination as Kautsky, the agricultural program was not the main object of dissension. The "Bavarians" had questioned the revolutionary interpretation of dialectic philosophy; ${ }^{2}$ they had publically pronounced "possibilist" opinions on the practical work of the party. ${ }^{3}$ By these opinions they had been led to the decision to vote for the state budget when its provisions seemed to represent significant social progress, in the face of the tradition which required the socialists to express their opposition to the bourgeois state by a negative vote on the budget, and in federations such as the German Reich not only on the federal but also on the state budgets. Nor was the significance of these heresies lost on all French Marxists: In an article in 1892 , the Guesdist paper Le Socialiste had called Vollmar a traitor. ${ }^{4}$ Yet two years later a man of the inner council of the Guesdist

1 The reference is to Bismarck's antisocialist law, which deprived the German Social Democraticparty of legal status, forced its whole journalisticand propagandaactivities underground or into camouflage, and led to imprisonment and banishment of leaders and subleaders.

2 "The life of society and of the state does not consist of leaps and somersaults, but of a series of fluctuations resulting in shifts of power, in partial successes (nicht aus sich uberscblagenden Spriungen, sondern aus einer Kette von wechselnden Verscbiebungen der Macbtverbältnisse, von Teilerfolgen). From the address by Vollmar at a meeting on June 6, I891 in Munich (so-called second Eldorado address). See Georg von Vollmar, Über die nächsten Aufgaben der deutschen Sozialdemokratie, München (M. Ernst) I899, p. I 8.

a "The pilgrim on his long and hard way to a distant goal cannot maintain his vital strength merely by looking at the contour of the goal appearing through the mist in a distance; he would die from hunger and exhaustion long before reaching it. Therefore we shall have to turn from the ultimate (zeitumbegrenzte) goal to the immediate, from the absolute to the positive, without losing sight of the universal purpose of our efforts; besides the permanent program, we must have working programs which are concerned with the immediate future, and we must concentrate our strength on those individual postulates, which answer to the most urgent needs and which have the greatest chance of realization." Ibid., p. I9.

4 See the speeches by F. Kunert and by Vollmar himself at the Berlin party congress, 1 892. Protokoll über die Vethandlungen des Parteitages, pp. 200, 206. Having no access to the files of Le Socialiste - a rare library title - I have not been able to identify the article in which the term was used. 
party recommended neutrality in the struggle between the "traitor" and the defenders of the Marxist creed in Germany, and apparently Jules Guesde accepted the advice. The neutrality, which Bonnier recommended, was even somewhat lopsided: It cannot conceal his sympathy for the "Bavarians". Although in the passage on Victor Adler the nonintervention rule is mentioned, the reason why Bonnier wished to keep the Parti ouvrier out of the German controversy was obviously tactical expediency and divided sympathies rather than respect for the rule.

The rule itself was of questionable applicability in view of the character of the world socialist movement at the time, and this character must be considered to understand the significance of Guesdist neutrality in the Kautsky - Vollmar controversy. The various national parties felt as members of one big family united by common purposes. How these purposes were to be interpreted, what means for their achievement were regarded as admissible or illicit in principle, was the concern of all, and for every group in one country it was important to obtain the support of members of the sister parties for its particular interpretation. In 1889 , the French Possibilists had tried to reinforce their position by calling an international congress, and had sought and received the support of British trade unionists and socialists for that project; the Guesdists had counteracted the Broussist effort by enlisting, with the help of Engels, the support of the German party. ${ }^{1}$ In the great controversy on ministerialism from I 899 to 1904 , the struggle was fought on a broad international front. Even in the intermediate period, the International Socialist congresses were called upon to debate issues which were at the same time on the agenda of the national parties, such as the relationship to the anarchists, the way to celebrate the ist of May, and the agrarian question itself. Under these circumstances, "non-intervention" of one party in the affairs of the other could mean no more than refraining from the expression of opinions on the merits or demerits of individuals as leaders and on the advisability of minor technical moves. (In the debate on ministerialism, not even these restraints were upheld.) The neutrality toward the German party dispute which Bonnier recommended for the Guesdists meant that the orthodox Marxist faction in Germany was to be deprived of the support which, in the light of the precedents, they had a right to expect of the French Marxists. It meant that internationally the Parti ouvrier took a middle position between Reformists and orthodox Marxists, and it is easy to understand that this choice also had an effect upon the attitude of the French party toward the Reformists at home.

${ }^{1}$ See Mayer, Friedrich Engels, vol. II, pp. $392 f$. 
A second striking aspect of the Bonnier letter is the keen sense of rivalry which he felt toward the German Social Democrats. He feels gratified to see that the organizational unity of the German party cannot cover up the doctrinal rifts; he wonders whether this organizational unity is really an advantage as compared with the state of the French socialist movement consisting of a number of separate parties, and he evidently hopes that the inner struggles of the German party will, in the eyes of other members of the International, deprive it of any right to appear as the champion of socialist unity. This resentment against the German comrades was apt to create some sentiment of solidarity with French socialists of other shades of opinion, especially since, in all probability, these other socialists shared the feeling that it was time for the Germans to cease sermonizing the other sections of the International. Bonnier's attitude brings to mind Jaurès' outburst against the German party at the International Congress of Amsterdam, ten years later. ${ }^{1}$

For the significance of the agrarian program as a vehicle by which the spirit of Revisionism penetrated into Guesdism, Bonnier's insistence that the gens à principe must make a "positive" counterproposal supplies clear evidence. This was the kind of argument which the Reformists of all shades of opinion always used against the orthodox Marxists: Here is a practical problem, and instead of telling us how it should be handled, you refer us to the principles expressed in Das Kapital and the Communist Manifesto. The Marxists had a simple reply: Let the practical problem go unsolved if the only possible solution would be inconsistent with our principles; we have no obligation to show a smooth way of transition from capitalism to socialism - more than that: we would be insincere if we maintained that the way will be smooth. Whoever is unwilling to put up with the hardships of the revolutionary change which first the technological development under capitalism and then the upheaval of the proletariat will bring about, should keep out of our party. The Guesdist refusal to accept this answer is a measure of the distance which they had drifted from the orthodox creed.

The views expressed in the Bonnier letters, it is true, are those of a Marxist intellectual, living in a country not his own, whose only importance was that of a mouthpiece and an adviser to one of the great leaders of French socialism, Jules Guesde. The correspondence, however, fails to give the slightest hint of any disagreement between Bonnier and Guesde; nor can such an indication be found in other

${ }^{1}$ See Discours de Jaurès à Amsterdam, in: La Revue Socialiste, XL (I904), p. 3 II; Marcelle Auclair, La Vie de Jean Jaurès, Paris (Editions du Seuil) r954, p. $468 \mathrm{f}$. 
books mentioning the relationship between the two men. Guesde may not have agreed with every single sentence Bonnier wrote, but on important issues of political strategy, it seems that the Bonnier letters can be taken as evidence of Guesde's opinions.

After Engels' criticism of the Nantes program had appeared, Bonnier wrote an article in reply; in a letter to Guesde of February 10, I895, he makes the publication dependent on Guesde's judgment and mentions that "Lafargue would regard it with an unsympathetic eye" - a somewhat enigmatic statement, because neither in the letters nor in any other source is there any indication that Paul Lafargue failed to see eye to eye with Guesde and Bonnier on the agrarian program. "I think," Bonnier writes, "as I have told you, that it is time to resume our position in work on theory (de reprendre notre place théorique), in the face of the Neue Zeit and the Critica Sociale. We have slipped down to second place (nous sommes descendus au second plan). Let us at least remain active in theory, in the same way as in our practical struggle (ayons au moins notre theorie 'active', parallele à notre lutte)." But the article did not appear in print. More than a year later, on June 1,1896 , in another of the letters, Bonnier tells Guesde that he had published another article in Die Neue Zeit, this time on the socialist victory in the French municipal elections, describing the program of Nantes and the municipal reform program of Lyons (1892) as contributory factors, and that Kautsky had added two "sweet-sour" editorial notes to the article; in one of these, Bonnier reports he "said at the end that we have not refuted the article by Engels, but I will not take up that challenge. It is too late now, and then, as you would tell me with good reason, this would only be another object of strife (pierre de scandale) thrown into our socialist morass." But on June 22, he writes to Guesde that he is "at this moment engaged in a polemic with Kautsky on account of our electoral success" and that Kautsky has on this occasion attacked the program of Nantes; "I would not have replied to him if he had not added that we 'have not yet discussed the article by Engels'." Again Bonnier's reply to Kautsky was apparently not published, at any rate not in Die Neue Zeit. If Guesde, as seems likely in the light of Bonnier's remark in his letter of June I about the socialist morass, wanted the controversy to quiet down, this thought must have acquired added weight after the conciliatory

1 See Charles Bonnier, Die Gemeinderathswahlen in Frankreich, in: Die Neue Zeit, XIV: 2 (I895-96), pp. 27 Iff. The notes by Kautsky are on pp. 273 and 276. 
resolution adopted at the International Socialist Congress of London. ${ }^{1}$ Perhaps for this reason Guesde and Bonnier decided not to carry on the polemic with Kautsky.

Thus there was no international battle royal over the program of Nantes, but there was continued sniping. In a review of Gabriel Deville's book Principes socialistes in Die Newe Zeit (vol. XIV: 2, issue of September 16, 1 896, pp. 804 ff.), Kautsky restated Engels' arguments; in an article on the French national elections of 1898 , Bonnier attributed a large share in this new victory to the program of Nantes, as he had done in the case of the municipal elections of 1896 . (See Die Neue Zeit, vol. XVI: 2, issue of June 1, 1898, p. 343.) Kautsky, as editor of Die Neue Zeit, accepted another article by Dr. B. Kritschewsky who, without directly challenging Bonnier's interpretation, deprecated the magnitude of peasant support for French socialism (p. 469). While the international debate on the agrarian program faded out, the problem of how to win rural support remained on the agenda of the individual socialist parties. In Germany, the dissensions over the future of the peasantry and the chances of winning the small farmer for Social Democracy continued unabated and were soon complicated by the split within the Revisionist group, when some of the most ardent supporters of Bauernpolitik developed nationalistic tendencies with which Bernstein and his friends had as little sympathy as Bebel or Kautsky, and Vollmar hardly much more. ${ }^{2}$ In France, where the effort to win the small farmer had the support of almost all socialists, each faction contributed to the formulation of effective strategies for the achievement of this purpose. ${ }^{3}$ In many of the smaller countries, too, the socialist parties tried to attract parts of the agricultural population to their ranks, but in spite of local

\footnotetext{
${ }^{1}$ At the London International Congress, the discussion of the relationship of socialism and anarchism - leading up to the expulsion of all anarchists from the International overshadowed the discussion of the agrarian problem; since there was not much time to present the two antagonistic views on the latter, a compromise resolution was the only way out, and it was adopted almost unanimously; its essence was the declaration that, as far as the class struggle in agrarian areas was concerned, "the Congress leaves it to every nation to formulate... the ways and means most suitable to the situation of their country." International Socialist Workers and Trade Union Congress, London 1896. Report of Proceedings. London (Twentieth Century Press) n.d., p. 26.

2 This conflict over the deviations of this group from socialist internationalism came to a climax in 1913 when Gerhart Hildebrand, one of the extreme right-wingers, was expelled from the party. The extreme right wing controlled the editorial policies of the Sozialistische Monatshefte but was numerically insignificant.

3 See the article by Harvey Goldberg, Jaurès and the Peasant, in: International Review of Social History, vol. II (1957), pp. $372 \mathrm{ff}$., for the share of Jean Jaurès in these policies. The only socialist group opposed to the spirit of the Nantes program seems to have been the Allemanists. See ibid., p. 382.
} 
successes the prevailingly urban character of the socialist movement remained unaltered.

The principal significance of the efforts to win the peasant for socialism was its accelerating effect on the erosion of Marxist orthodoxy. Even in Germany, the speeches of Bebel at the Congress of Breslau (1895) showed, that at least this protagonist of traditional Marxism had somewhat tempered his zeal for the orthodox creed. 1 The French case, however, is particularly important because it was a Marxist group that took the lead in rejecting the dogma that socialism had nothing to offer the farmer who wanted to stay on his own property. The agricultural discussion in France demonstrates how hopeless the position of the Kautsky school was - and that applies equally to the position of the Guesdists after I 899 when they returned to their old intransigence. Bonnier's demand that Engels and Kautsky, if they rejected the Nantes program, offer a "positive" alternative was quite logical on the presupposition that support by a majority was indispensable for the victory of socialism. On this assumption, the French could well ask the dominant German group: What alternative method is there to open the road to a socialist victory in France? And they might have added: How can a world-wide victory of socialism be achieved unless socialism is victorious in France?

But the presupposition implied that the socialists could not rely on the operation of those historical forces which, according to Marx, made socialism inevitable; and, it also implied that the Blanquist idea of a revolution carried out by an urban elite, with the new rule imposed on the country until the masses would be educated to see the light, was also unacceptable or unworkable. Since the Kautsky Marxists rejected Blanquism and passive reliance on historical forces just as decidedly as did the Reformists and Guesdists, there was a logical cleavage in the orthodox position, which became a fatal weakness as the practical tasks multiplied and the need for practical solutions, which could not be fitted into the traditional Marxist pattern, became ever more urgent. The Guesdists, having returned to their old radicalism in 1899 , could not escape this weakness even after their outer triumph in 1905 , when they were able to impose their terms for unification on the Reformists, just as the outer triumph of the Kautsky faction at the Dresden party congress of $190_{3}$ failed to prevent the penetration of German Social Democracy by the ideas

${ }^{1}$ See Protokoll über Verhandlungen des Parteitages zu Breslau, Berlin (Vorwärts) i 895, esp. pp. II $5 \mathrm{ff}$. The Congress, however, rejected the draft of an agricultural program submitted by a committee of which Bebel as well as Vollmar and other advocates of a pro-farmer policy were members. 
of Bernstein and Vollmar. Only in those countries in which conditions favored an essentially Blanquist strategy - which of course was also a deviation from Marxist orthodoxy, only in an opposite direction - could Marxists escape from the compulsion to a reformist strategy: It was through the strategy of the revolutionary elite that Lenin established a regime to which he applied the Marxian term of the dictatorship of the proletariat and laid the foundation for an agrarian policy which, after a breathing spell, meant not the winning but the overpowering of the peasantry. 